Article

\title{
Re-Conceptualizing Safety of Journalists in Bangladesh
}

\author{
Mubashar Hasan ${ }^{1, *}$ and Mushfique Wadud ${ }^{2}$ \\ ${ }^{1}$ Department of Culture Studies and Oriental Languages, University of Oslo, 0315 Oslo, Norway; \\ E-Mail: mubashar.hasan@gmail.com \\ 2 Reynolds School of Journalism, University of Nevada, Reno, 89557, USA; E-Mail: mwdipu@gmail.com \\ * Corresponding author
}

Submitted: 26 September 2019 | Accepted: 17 December 2019 | Published: 25 February 2020

\begin{abstract}
Journalists are currently facing a multitude of threats. Commonly, these are considered in terms of harassment and bodily harms such as incarceration and murder of journalists. In the Bangladeshi case we argue that the parameters for evaluating what constitutes safety for journalists go beyond conventional wisdom. On the basis of in-depth interviews of 23 Bangladeshi journalists, we argue that the concept of journalists' safety has three intertwined dimensions. First, journalists' safety incorporates avoiding bodily harm (imprisonment, enforced disappearance, and so forth), and harassment, as well as economic and career threats. Second, in order to remain safe, journalists undertake various tactics including compromising the objectivity of news in a regime where security apparatus and pro-government journalists work in tandem to surveil and intimidate non-partisan journalists. Third, the tactics used by journalists decrease public faith in the media and the media can no longer play a watchdog role. We argue that one needs to reconceptualize the safety of journalists within these three intertwined dimensions.
\end{abstract}

\section{Keywords}

authoritarianism; Bangladesh; democracy; hybrid regime; journalism; journalists' safety

\section{Issue}

This article is part of the issue "Rethinking Safety of Journalists" edited by Kristin Skare Orgeret (Oslo Metropolitan University, Norway) and William Tayeebwa (University of Makerere, Uganda).

(C) 2020 by the authors; licensee Cogitatio (Lisbon, Portugal). This article is licensed under a Creative Commons Attribution 4.0 International License (CC BY).

\section{Introduction}

Safety of journalists has context-specific meanings and implications. For example, a journalist who is working at the New York Times in the democratic USA will have different standards for safety (and its preservation) from a journalist working in Rwanda or Pakistan where democratic institutes, norms, and cultures are under pressure. In light of this basic presumption, we sought to find out how Bangladeshi journalists define the concept of "safety." UNESCO (2019) conceptualizes the lack of safety for journalists as "attacks on media professionals often perpetrated in non-conflict situations by organized crime groups, militia, security personnel, and even local police, making local journalists among the most vulnerable." It says that these attacks include murder, abductions, ha- rassment, intimidation, illegal arrest, and arbitrary detention (UNESCO, 2019).

According to Bertelsmann Stiftung, a think tank based in Germany, Bangladesh is a new autocracy (Schwarz, 2018). However, Riaz (2019) differs with this view and argues that Bangladesh is a hybrid regime-a regime that combines democratic traits (election) with autocratic traits (severe political repression). In other words, Bangladesh is not a country that respects democratic principles such as free speech, human rights, and political equality. Within this political climate, the government has made heavy investments in procuring surveillance technology and employs various surveillance techniques to thwart free thinkers and journalists (Privacy International, 2018). As a result, the 2019 World Press Freedom Index placed Bangladesh at 150th out 
of 180 countries and Bangladesh is below Afghanistan and Pakistan (Reporters Without Borders, 2019). The Freedom in the World 2019 report said "journalists and media outlets in Bangladesh face many forms of pressure, including frequent lawsuits, harassment, and serious or deadly physical attacks" (Freedom House, 2019). In addition, Human Rights Watch has noted repeated abuse of "section 57 of the ICT Act to prosecute journalists" (Human Rights Watch, 2018a). Section 57 of the ICT Act authorizes prosecution of any person who publishes, in electronic form, material that is defamatory and prejudices the image of the state or a person or causes or may cause hurt to religious belief. A Bangladeshi think tank, Article 19, notes that "in 2017, there were 76 incidents of journalists facing charges under Section 57 of the ICT Act, and in 2018 there have been more than 90 cases brought against activists, media workers, and others" (Article 19, 2018). In 2018, Bangladeshi editors formed a human chain to protest another anti-free speech law entitled the Digital Security Act. The law, called a "black law" by many, could send anyone to prison for 7-14 years who "secretly records government officials or gathers information from a government agency using a computer or other digital device" and "spread(s) negative propaganda about the country's 1971 war of independence and its founding leader Sheikh Mujibur Rahman" (Mahmud, 2018b). Against this backdrop of increasing surveillance and attacks on journalists by force and legal means in a political climate that is not democratic, we investigate how Bangladeshi journalists define safety. On the basis of our findings we will discuss safety issues for journalists in the face of ever-expanding censorship, journalists' reactions and defense against safety risks, and how the public views the role of media in the country.

\section{Framing the Problem of Safety and the Agency of Journalists in a Hybrid Structure}

Goffman has argued, "individuals cannot understand the world fully and therefore actively classify and interpret their life experiences to make sense of the world around them" (Goffman, 1974, p. 24). The individual's reaction to sensory information therefore depends on schemes of interpretation called "primary frameworks" (Scheufele, 2000). In short, framing theory underpins how an interconnected world can be subdivided through particular frames that conceptualize or address an issue. Ajzen and Fishbein (1980), Nelson, Clawson, and Oxley (1997), and Chong and Druckman (2007) argue that framing starts with a conventional expectancy value model of an individual's attitude toward an object or issue. The debate about climate change is a good example in this regard. In this debate there are groups and individuals who believe that changes being observed in the climate are dangerous and therefore want to reduce greenhouse gas emission, whereas there are groups and individuals who believe that climate change is a hoax and, therefore, that there is no need for reducing greenhouse gas emission.
This debate demonstrates that individuals form attitudes towards actions as a result of holding a set of beliefs about climate change. The set of dimensions that affect an individual's evaluation of climate change constitutes an individual's "frame in thought" and their attitude to the debate is considered to be a "framing effect" (Chong \& Druckman, 2007, p. 106). In our study, we will need to decipher how journalists frame the problem of safety in Bangladesh against the backdrop of the authority (the state and media owners) systematically subverting free media in Bangladesh. The relationship between journalists and authority in the current age of the hybrid regime is further explainable through agents and structure theory because the frame in thought and framing effect in any consideration of the safety of Bangladeshi journalists is embedded in the power relationship between the agency of journalists and the structure of their society, i.e., the hybrid regime of Bangladesh.

Dowding (2008) argues that individual human beings are agents and their behaviours and attitudes are shaped and moulded by structures of their environment. In this regard Dowding asserts that "both the social or institutional rules and the interests of other people-will structure the behaviour of agencies of biological individuals" (Dowding, 2008, p. 22). How journalists behave in order to remain safe in the face of oppressive political institutions is important to know. However, we should also reinforce the fact that the attitudes of journalists confronting the hybrid regime are conditional on the power relationship between the agents (Bangladeshi journalists) and structure (the hybrid regime; for more, see Bucholtz \& Hall, 2005, p. 607).

\section{The Media Landscape of Bangladesh}

Outlets for journalists have gone through a transition in Bangladesh in the last few decades due to the emergence of satellite televisions and the expansion of the Internet. According to one estimate, in 2017 there were 2,320 newspapers, 1,781 online news sites, 72 radio stations, and 43 television channels in Bangladesh (Bour, Frey, \& Rahman, 2017, p. 23). Bour and colleagues also note that there are 17,300 organized journalists working in Bangladesh (Bour et al., 2017). However, this account of the media landscape is not in accord with other estimates, which claim that the total number of private television stations operating in Bangladesh is 30 and the total number of newspapers is 1,191(Azad, 2018; Islam \& Jahan, 2019). Despite this question about the precise number of media outlets, it is plausible to conclude that journalism and news are being disseminated through diverse media channels in the country and that many people are working as journalists. However, the quality of journalism in Bangladesh is not encouraging. Elahi (2013), on the basis of a survey of 333 journalists who are based in Dhaka (capital of Bangladesh), in-depth interviews, and focus group discussions, found that journalists' ethical standards are poor and that many indulge 
in corrupt practices. Elahi also found that "some journalists and certain sectors of the media imposed selfcensorship because of journalists' and editors' personal political bias or the media owner's political position" (Elahi, 2013, p. 197).

\section{The Scope of This Study: Safety of Journalists in Bangladesh}

Safety of journalists has remained an understudied terrain for scholars and practitioners. In 2014, with the aim of filling this gap, UNESCO developed a ten-point research agenda in line with the 2011 UN Plan of Action on the Safety of Journalists and the Issue of Impunity, and called for journalists to cooperate with academic scholars (Fadnes, Krøvel, \& Orgeret, 2019, p. 2). That research agenda included-"Rights-based issues; Conflict issues; Societal issues; Legal issues; Practitioner issues; Psychological issues; Economic issues; Digital issues; Thematic issues; Educational issues" (Fadnes et al., 2019). Before this push from UNESCO, it was "challenging to examine the issue of safety due to the politically sensitive features of the topic and the need to continuously strive for consensus within a multi-national organization" (Fadnes et al., 2019).

We have found three limitations in previous studies of journalist safety. First, we found that most studies on the safety of journalists stemmed out of conflict and reporting of war zones (Ashry, 2019; Aslam, 2015; Creech, 2018; Düsterhöft, 2013; Eide, Khalvatgar, \& Shirzad, 2019; Greppi, 2004; Høiby \& Ottosen, 2017; Kim, 2010; Lisosky \& Henrichsen, 2009; Relly \& Bustamante, 2014; Saboory et al., 2017; Tumber, 2006). Journalists' safety in stable authoritarian or hybrid regimes like Bangladesh hardly gets scholarly attention. Second, we found that the term 'safety' largely is limited to harassment, incarceration, and bodily harms in the small number of scholarly papers written about the safety of journalists in places that are not war and conflict zones (Baker, 2016; Saboory et al., 2017). Some articles talk about arrests of journalists and attacks on news outlet offices (Diedong, 2016; Srinivasan, 2016). A few talk about safety issues that journalists face in the virtual world (Barton \& Storm, 2014; Çalışkan, 2019). However, very few talk about broader aspects of journalists' safety including the hazards associated with journalists' need to compromise objectivity in order to remain safe. Finally, in the Bangladeshi context, journalists' safety is a neglected topic as well, as we found only three papers addressing elements of safety of Bangladeshi journalists. For example, Akhter and Ullah (2014) examined the safety issues of local correspondents when covering natural disasters like cyclones, whereas Ahmed (2016) studies the issue of self-censorship in the press. Islam and Rahman (2016) investigated actors behind the suppression of freedom of the press.

As scholarship on the broader aspects of the safety of journalists in Bangladesh is rare, we have surveyed annual reports published from 2009-2019 from Reporters
Without Borders, Freedom House, and the Committee to Protect Journalists. We found that these reports are also limited to the conventional concept of journalist safety as they highlight physical attacks, arrests, self-censorship, murder, and laws restricting freedom of speech (for instance, see Committee to Protect Journalists, 2009, p. 13, 2015 , p. 7, 2017, p. 1, 2018, p. 21). It is our hope that by expanding the paradigm of the safety of journalists we will encourage scholars and practitioners to rethink the issue of journalist safety in Bangladesh.

\section{Research Design: The Method}

We employ both qualitative and quantitative research methods to understand how journalists conceptualize safety issues, what techniques they use to remain safe in the face of burgeoning efforts by the government to control the media, and how the public reacts to journalism. To understand how journalists define safety we sent a qualitative, open-ended questionnaire to 30 former and current journalists in October 2019. Among them, 23 replied. As we both had been journalists in Bangladesh, we could, as Palinkas et al. $(2015$, p. 3) said "identify and select individuals or groups of individuals that are especially knowledgeable about or experienced with a phenomenon of interest" for our purposive sampling technique. Our questionnaire involved 19 questions (see Supplementary File).

Our logic behind the framing of this questionnaire was embedded in several factors. First, we contextualized the questions based on the recent reports coming out of Bangladesh about the status of the free press and safety of journalists. Reporters without Borders recently observed "serious press freedom violation" in the country as mentioned in the beginning of this article. For example, while covering the road safety movement by Bangladeshi school children in 2018, five photojournalists including one from the Associated Press were severely beaten by men from the ruling party (The Daily Star, 2018). A well-known photographer, Shahidul Alam, was arrested and imprisoned for 100 days for offering criticism about the government in an Al Jazeera TV interview during the road safety movement (Ahmed, 2018; Laurent, 2018). Therefore, a key frame that dominates our questionnaire is rooted in exploring connections between the suppressive nature of the regime and journalists' perceptions about their safety (for example, see Supplementary File, questions a to f). This approach is also justified through agency and structure theory as mentioned above, since we believe it is impossible to understand the agencies of journalists living in Bangladesh without acknowledging that their agencies are molded, shaped, and reshaped by the authoritarian political structure of Bangladesh. Following Schlosser (2015) we consider agencies to be the capacity of journalists to act as journalists and we again note that the concept of safety is embedded within journalists' agencies. As previously mentioned that professional bodies for measur- 
ing quality of democracy downgraded Bangladesh for being an authoritarian regime, we believe that the safety of journalists working in Bangladesh is dependent on the agents guarding the authoritarian government structure; hence we have framed our questions in this manner. Finally, we followed Stanford University Professor Jon Krosnick, who received a life-time achievement award for outstanding research by the American Association for Public Opinion Research, in choosing open-ended questions. In his opinion "open ended questions prove to be more reliable than closed questions and in lots of different studies of validity, open questions prove to be superior to closed questions" (Vannette \& Krosnick, 2018, p. 443). Our selection of words in our open-ended questions was "simple, direct and comprehensible" and we avoided any jargon, as suggested by Vannette and Krosnick $(2018$, p. 444).

To protect the safety of the journalists participating in this research we did not record their names. Out of the 23 respondents, 7 are no longer working as journalists. Four of the ex-journalists said they switched jobs out of insecurity, one said that he/she is teaching journalism now rather than working as a journalist, one said he/she is pursuing higher studies, and one is now working as a social media strategist for a public relations company. Seven respondents said they had been journalists for 20 to 30 years, 9 respondents said they had been journalists for 10 to 20 years, and the experience range of the rest of the respondents was between 3 and 10 years. Positions of the respondents in the journalism industry included: broadcast journalist, assignment editor, sub-editor, diplomatic correspondent, social media coordinator for news media, assistant editor, special correspondent, executive editor, editorial assistant, news editor, senior reporter, bureau chief of a foreign news agency, editor, and news chief. We believe the diverse background of our respondents in terms of their experience and positions are representative of the journalism sector of Bangladesh. A drawback of our research, however, is that our sample is not free from gender bias, as only three of the respondents are female. We further acknowledge that our purposive sampling strategy may not be free from bias as we only reached out to journalists who we know. One difficulty that we encountered was that in analyzing their responses we had to rethink our own safety and carefully consider what to write and what not to write, who to name and who not to name.

Our social media content analysis was targeted at investigating peoples' perceptions about Bangladesh's media during a 2018 student movement for reforming the quota system in government jobs (Mahmud, 2018a). The government first used force to quash the protest. Against that backdrop, student activists and supporters raised questions about the fairness of the Bangladeshi media in covering that event. Activists and students in favor of the movement have accused the media of bias. In their opinion, the media was protecting the interests of the government when some of the news reports vilified lead- ers of that student movement as Islamists and opposition party activists.

A student platform called Sadharan Chhatra Adhikar Sangrakshan Parishad (the platform for protecting rights of general students) led that quota reform movement. That platform has a Facebook group with 1,094,663 members. After joining the group, we searched group posts and critical comments about media and journalism. When we searched for the Bengali phrase Holud Shangbadikota meaning "yellow journalism" in English in the group, we found a total of 200 posts addressing topic related to credibility of journalism. We have selected 50 posts and comments and encoded them. We only selected Facebook posts that appeared during the 2018 student movement as we wanted to understand the public's perception about the media at this time. The posts were categorized thematically based on the following criteria: (a) accusing the media of presenting incorrect/false information about the movement; (b) accusing the media of being biased towards the government; (c) provided a personal narrative of the movement that contradicted the media representation; (d) TV talk show videos labelling student activists as Islamists and opposition activists; (e) photos demonstrating general acceptability of the movement among students while denouncing media coverage. Posts were selected on the basis of their popularity (at least 300 likes) and presence of comments from other users (at least 100 comments).

A year after that movement, in 2019, we asked the following two questions to the general public: (1) To what extent do you think the news you read in Bangladeshi media is true and accurate; and (2) to what extent do you think the news about Bangladesh you read in foreign media is true and accurate?

We shared this survey on our Facebook pages in September 2019 via a Google document and asked random people to participate. Our questionnaire included options to provide both open-ended and close-ended answers, i.e., a respondent could mark "yes" or "no" and there were options for them to write further. In total, over a period of a week, 139 respondents filled out the form. They came from diverse backgrounds including student, teacher, businessperson, engineering professional, physician, rights defender, information and communication technology professional, public relations professional, and government service worker.

\section{Finding 1: Journalist Responses-Bodily Threats, Psychological Threats, Digital Threats, and Censorship}

An overwhelming majority of the journalists (21 out of 23) identified physical threats including bodily harms such as being arrest, imprisonment, and enforced disappearance as key safety concerns. Psychological insecurity stems from living in constant fear of becoming a victim of bodily harm, losing a job, or being bullied or harassed by pro-government journalists. In the words of a respondent: 
No one is safe in this country. The law enforcing agencies could pick up anyone and enlist them as criminals. Within this milieu journalists are more vulnerable. In the past $5 / 6$ years many cases were filed against the journalists. Pro-government party members have beaten journalists when they wish, and they are still doing it with full impunity. For that reason, I feel insecure all the time; because of this insecurity I refrained from publishing my personal political thoughts in social media. (Personal communication)

Such concerns are not unfounded as at the time of writing this article, in a Bangladeshi district Sylhet, a journalist was picked up by plain-clothed law enforcement officers, and in the aftermath, 56 local journalists filed a general diary to local police station fearing their security (Manab Zamin, 2019). In Bangladesh, general diary is a legal form of registering concern that incidents are happening or likely to happen within the jurisdiction of a local police station.

Another journalist, who used to work as an editorial writer in a leading national daily and who left the job for the fear of his safety, recollected his trauma during his time as a journalist in the following way:

I did not feel safe. My family was terrified about my safety as I used to pen critical columns in the newspaper where I used to work. The feeling of insecurity was heightened whenever an article was published in the newspaper. In the night I was worried that law enforcers would knock the door to pick me up, and in the day I was anxious to get a call from security officials. (Personal communication)

However, not every respondent feels insecure as one respondent said, 'I do not think the situation is so bad that journalists should feel insecure; rather I would say journalists have created an unjustified fear for themselves and apply self-censorship' (personal communication). Even this sceptical statement is an endorsement that journalist community in Bangladesh is engulfed with fear and insecurity.

At the time of conducting our research, a deep threat of losing jobs engulfed the Bangladeshi media scene. The Bengali service of the British Broadcasting Corporation reported, without mentioning an actual number, that private TV channels and radio stations were laying off officials and journalists; a private TV channel had closed operation of its news section (Kollol, 2019). The Germanybased Bengali news service, DW Bengali, reported that 25 journalists were fired from Bangladesh's top Bengali newspaper (DW Bengali, 2019). Such scenes have had an impact on journalists and they live under a relentless psychological pressure rooted in job insecurity (and thus economic insecurity), as illustrated by the following response, "now for us, economic security has become a major issue. For this reason, big portions of journalist community do not want to pursue objective journalism or represent all facts in a story (personal communication).

Another respondent opens up a different avenue in which one can see journalists' fear of losing jobs, and/or being bullied and harassed, as connected to compromising objectivity of news. The respondent said, "if we lose our jobs, there will be a campaign by the pro-government journalists against us as anti-national, anti-state, terrorists. For this reason, to remain safe, we sometimes refrain from telling the truth" (personal communication).

There was also a perception of digital threats, including fear of phones being tapped or digital surveillance. Human Rights Watch reported that the Bangladesh government has embarked upon an "intensive and intrusive surveillance and monitoring of social media" (Human Rights Watch, 2018b). “I don't feel safe anymore. I am in constant fear that my phone is being tapped and my journalism is being under constant watch by people in the security agencies," said a respondent (personal communication).

Media houses that are deemed to be critical about the government have also been targeted. A journalist working for the leading English newspaper, The Daily Star, said:

As has been documented, pressure from the government came upon The Daily Star in an indirect wayour advertisers were squeezed. As a result, big telecoms stopped advertising with the newspaper, while other companies constantly cited the government's disapproval of the newspaper as a reason to not give advertisements. This has significantly hampered our ability to cover [sensitive] issues such as military affairs, among other matters. (Personal communication)

Another respondent said the list of people and organizations who journalists can't scrutinize is getting longer. In that respondent's view, 10 years ago only the family members of the top political leadership and elite intelligence agency were protected from scrutiny; now it is frequently the case that journalists can't report on powerful ministers and advisers. Not only that, the respondent said, "we can't even write about mid-career police officials because fact-based investigative reports are not being tolerated" (personal communication). Another respondent, a former journalist who left the profession out of frustration after 15 years said, "partisan editors and media owners with political ties are deterring objective news" (personal communication). Another respondent who used to work for a local television channel said that a top wing of the government maintains a list of progovernment and anti-government journalists. He was labelled as anti-government and his promotion was halted; eventually he had to leave the country. Later, at the same television channel, some of his colleagues tried to pursue sensitive stories objectively and they were also labelled as anti-government. However, it is beyond our scope to validate these claims. 


\section{Finding 2: Journalists Reactions and Defence against Safety Risks}

In order to cope with fear, insecurity and threats, journalists are adopting multiple defence mechanisms that compromise the quality and objectivity of news. Sometimes, to remain safe, they choose not to report.

Against this backdrop, our research recorded a disturbing yet evolving practice in which journalists promote the administrations' agenda or apply selfcensorship on sensitive issues to remain safe. For example, one respondent said:

Some journalists just work as part of the government PR machinery and the security agencies because they know that they will gain financially through their reporting. And on occasions when they stumble upon a report that can seriously damage the government's reputation, these journalists just kill the story or don't even mention its existence to their news editors and newsroom managers. (Personal communication)

One respondent explained why he had to leave the profession as a result of his quest for pursuing what he deemed objective journalism:

I believe I was driven out of objective journalism. The current situation is not at all supportive for objective journalism in Bangladesh, because you need to be a party loyalist; more clearly, you have to support the ruling party polices and their rules. In another way, you need to be a pro governmental journalist, where you are allowed to dig into the positives of the regime. (Personal communication)

There are differences among our respondents about whether journalists are forced to get involved in this practice, as some said there are journalists who are enthusiastic about promoting the government agenda out of self-interest, whereas others said they are forced to promote the government agenda. One respondent pointed out that "if journalists do not promote government agenda the government simply cuts off access" (personal communication) referring to two top newspapers in Bangladesh not having access to the Prime Minister's press conference. When they do try to report the truth, they are increasingly met with in-house censorship. One crime reporter who was investigating extrajudicial killing of alleged rapists found out that a government agency was behind the killings. The reporter reached this conclusion by tracing the license plate of a vehicle that was used to kidnap one victim. However, when his report was published, he saw the editor had erased the name of the government agency that had registered the vehicle.

\section{Finding 3: Diminishing Public Faith in Media}

Wanta and $\mathrm{Hu}$ (1994) have argued that the success or failure of news media's efforts to educate, inform, pursue, and influence media audiences can often depend on the audiences' overall perception of media credibility.

In our analysis of social media posts we found that a general perception in the public that journalists do not provide people with accurate news. In all of our selected posts, group members were labeling journalists as "yellow journalists." One popular post argued that: "The country is heading in a bad direction because of "yellow journalism."' Another said, "when journalists cannot provide us with true and accurate news, how can we have trust in media?" A third post reads "we should boycott the journalists who spread fabricated news after compromising their moral and conscience." The person did not clarify what he meant by 'boycott.'

In our survey about media credibility, of 139 respondents, only one individual agreed that he/she gets accurate news from Bangladeshi media outlets (see Table 1 ).

By contrast, a total of 33 respondents (23.9\%) agreed that they receive accurate news about Bangladesh in foreign media outlets. 71 respondents (51.4\%) partially agree that they get accurate news from foreign media outlets about Bangladesh (see Table 2).

In response to a question about the credibility of media outlets in Bangladesh, most respondents said that they think local news outlets are biased and tend to hide news. One respondent said, "Bangladeshi TVs have zero credibility" (personal communication). Another respondent said, "now all the journalists can be bought by money" (personal communication). In response to a question about why they think foreign media outlets tend to provide them with true and accurate news, one respondent said, "they are not directly con-

Table 1. Public perception about credibility of the local media in Bangladesh.

\begin{tabular}{|c|c|c|c|c|}
\hline & $\begin{array}{l}\text { Question: Bangladeshi owned media outlets are } \\
\text { credible and provide you with objective news }\end{array}$ & $\begin{array}{l}\text { Results in percentage } \\
(\%)\end{array}$ & $\begin{array}{l}\text { Number of } \\
\text { respondents }\end{array}$ & $\begin{array}{l}\text { Total } \\
\text { respondents }\end{array}$ \\
\hline 1 & Strongly Agree & 0 & 0 & \multirow{6}{*}{139} \\
\hline 2 & Agree & 0.7 & 1 & \\
\hline 3 & Partially Agree & 28.3 & 39 & \\
\hline 4 & Partially Disagree & 5.1 & 7 & \\
\hline 5 & Disagree & 30.4 & 42 & \\
\hline 6 & Strongly Disagree & 35.5 & 50 & \\
\hline
\end{tabular}


Table 2. Public perception about credibility of international media in Bangladesh.

Question: Western News outlets in Bangladesh (such as BBC,

AFP, DW, AP) are credible and provide you with objective

Results in Percentage

Number of

Total

news about Bangladesh

(\%)

respondents

respondents

1 Strongly Agree

2 Agree

5

7

23.7

51.1

33

Partially Agree

5.6
8.6

71

Partially Disagree

8.6

12

Disagree

Strongly Disagree

2.9

139

trolled by the government. Owners of these media are not beneficiaries of the present government" (personal communication).

\section{Discussion}

Our findings demonstrate that for Bangladeshi journalists, safety encompasses job security, self-censorship, avoiding bodily harm (imprisonment, enforced disappearance, and so forth), avoiding harassment, and opting for agenda promotion of the government. A second crucial finding is that journalists compromise the objectivity of the news to maintain personal safety. Almost all of our respondents (except those who are working in foreign media) said that it is nearly impossible to pursue objective news reporting on certain issues due to the existence of what we call a "censorship machine" in Bangladesh. We describe this censorship effort as a machine because it has many processing tools (such as intimidation by the security and political apparatus, harsh laws, etc.) and the objective of these tools is to produce a finished productfinely processed news. This processed product is not a true reflection of the facts as some facts have been censored by the censorship machine. In this regard names of two key government offices were cited by the journalists repeatedly but we are not naming them. Various agencies within the security establishment (some of which are well known for suppression of human rights and free speech), partisan media owners, repressive laws like digital security act, and fellow partisan journalists are all involved in the censorship machine.

Finally, we find that the impact of the censorship machine on journalists in Bangladesh has contributed negatively to the public perception of the credibility of journalism. The steps that journalists feel they must take to ensure their own safety is implicated in dwindling media credibility. This paradigm is a consequence of a censorship machine conditioned by the hybrid regime. As a result, the media is no longer playing the role of the Fourth Estate in the country. In our view, this observation by James Carey fits the Bangladeshi case very well, since Bangladesh now is not democratic: "When democracy falters, journalism falters, and when journalism goes awry, democracy goes awry" (Carey, 2007).
The Bangladesh story however is applicable to a wider global pattern as more than one third of the world's population live in declining democracies in which authoritarian, hybrid, and populist regimes are rising who clamp down on the free press (Hodal, 2019; Lührmann \& Wilson, 2018, The Economist, 2018). Only $13 \%$ of the world's population now enjoys a free press, and press freedom is under severe threat even in democracies (The Economist, 2018). In non-democracies-in Africa, Middle East and Much of Asia-most governments are adhering to the Chinese model of suppressing free media. They favor the sophisticated censorship of the Beijing model which is premised on the idea that "prosperity can be achieved without a free press" over the Western model which values "strong and consistent associations between unfettered media and vibrant democracies" (The Economist, 2018). These findings paint a depressing outlook, and indicate that the safety of journalists should be a matter of continuous public discussion in the coming days. Our Bangladesh study demonstrates the need for expanding the framework of safety of journalists by incorporating journalists' defense mechanisms and their impact on the public. A cause for concern regarding Bangladeshi journalists, however, is that previous research has suggested that journalists are more unsafe in hybrid regimes like Bangladesh than in a pure autocracy. Hughes and Vorobyeva (2019) found that countries with hybrid regimes are by far the most dangerous environment for journalists as power holders have incentives to violently suppress critical press coverage. They reached this conclusion after analyzing 1812 killings of journalists from 1992 to 2016. Such findings offer insight as to why journalists we interviewed in Bangladesh are compromising their own integrity to remain safe while living and working in a hybrid regime.

\section{Conclusion}

Fear dominates the responses we received and it was an eye opener for us. Although we both were insiders at some point of our lives as both of us have worked as journalists in the country, now we are outsiders. Before this research we had some idea that local journalists were going through some difficulties, as we maintain close con- 
tacts with our journalist friends in Bangladesh and follow current affairs. However, we did not have a clear picture about the magnitude of fear and the prevailing feelings of insecurity until we conducted this research.

Through our research we believe that we are justified in putting forward three major arguments: (a) Safety of journalists in Bangladesh is a broad concept as it includes opt to government agenda promotion alongside of the conventional wisdom about journalists' safety; (b) when journalists feel unsafe, there are serious implications for the quality of journalism, as compromising objectivity to maintain personal safety is a common phenomenon in the Bangladeshi context; and (c) the compromise of objectivity in order to preserve safety results in the erosion of media credibility in the eyes of the public. So what does it mean for Bangladesh and its practice of journalism? In our view, the prevailing model of journalist safety is detrimental not only for the journalists' health and well-being, but also for the growth of journalism as a profession.

\section{Acknowledgments}

We are grateful to Dr. Barbara Jasny and Professor Arild Engelsen Rudd for their proof reading and editing support. We also acknowledge two reviewers for their insightful comments and Dr. Kristin Skare Orgeret of Oslo Metropolitan University.

\section{Conflict of Interests}

The authors declare no conflict of interests.

\section{Supplementary Material}

Supplementary material for this article is available online in the format provided by the authors (unedited).

\section{References}

Ahmed, A. M. (2016). Official secrecy, self-censorship and political parallelism: A study on the Bangladesh press. Media Asia, 39(1), 23-31. https://doi.org/10. 1080/01296612.2012.11689915

Ahmed, Q. (2018, August 9). Why did Bangladesh arrest Shahidul Alam? Al Jazeera. Retrieved from https:// www.aljazeera.com/indepth/opinion/bangladesharrest-shahidul-alam-180809112820231.html

Ajzen, I., \& Fishbein, M. (1980). Understanding attitudes and predicting social behavior. Englewood Cliffs, NJ: Prentice-Hall.

Akhter, R., \& Ullah, M. S. (2014). News coverage of cyclones and risk exposure of journalists in Bangladesh. Mass Communicator: International Journal of Communication Studies, 8(3), 4-11. https://doi.org/10. 5958/0973-967X.2014.00001.5

Article 19. (2018). Bangladesh: Release of Shahidul Alam must be followed by dropping of charges and reform of repressive laws. Article 19. Retrieved from https:// www.article19.org/resources/bangladesh-releaseof-shahidul-alam-must-be-followed-by-droppingof-charges-and-reform-of-repressive-laws

Ashry, M. A. (2019). Legislative international framework to protect the journalists in armed conflict zones in the Middle East. Global Media Journal, 17(32), 1-11.

Aslam, R. (2015). Media, politics and the threats to journalists in Pakistan. Pacific Journalism Review, 21(1), 177-194. https://doi.org/10.24135/pjr.v21i1.156

Azad, M. A. (2018). Bangladesh. Media Landscapes. Retrieved from https://medialandscapes.org/country/ bangladesh/organisations/trade-unions

Baker, A. (2016). The safety of Al Jazeera English journalists in Egypt. Global Media Journal-African Edition, 10(2), 38-91.

Barton, A., \& Storm, H. (2014). Violence and harassment against women in the news media: A global picture. Washington, DC, and London: International Womens Media Foundation and International News Safety Institute. Retrieved from https://www.iwmf.org/ wp-content/uploads/2018/06/Violence-andHarassment-against-Women-in-the-NewsMedia.pdf

Bour, H. E., Frey, E., \& Rahman, M. G. (2017). Media landscape in Bangladesh, Norway and Tunisia. In E. Frey, M. Rhaman, \& H. E. Bour (Eds.), Negotiating journalism: Core values and cultural diversities (pp. 23-37). Gothenburg: NORDICOM.

Bucholtz, M., \& Hall, K. (2005). Identity and interaction: A sociocultural linguistic approach. Discourse Studies, 7(4/5), 585-614.

Çalışkan, B. (2019). Digital security awareness and practices of journalists in Turkey: A descriptive study. Conflict \& Communication Online, 18(1), 1-16.

Carey, J. W. (2007). A short history of journalism for journalists: A proposal and essay. Harvard International Journal of Press/Politics, 12(1), 3-16.

Chong, D., \& Druckman, J. N. (2007). Framing theory. Annual Review of Political Science, 10, 103-126.

Committee to Protect Journalists. (2009). 2009-2010 annual report of committee to protect journalists. New York, NY: Committee to Protect Journalists. Retrieved from https://cpj.org/about/CPJ.2009.2010. Annual.Report.pdf

Committee to Protect Journalists. (2015). 2015 annual report of committee to protect journalists. New York, NY: Committee to Protect Journalists. Retrieved from https://cpj.org/about/CPJ.2015.Annual.Report.pdf

Committee to Protect Journalists. (2017). 2017 annual report of committee to protect journalists. New York, NY: Committee to Protect Journalists. Retrieved from https://cpj.org/about/CPJ.2017.Annual.Report.pdf

Committee to Protect Journalists. (2018). 2018 annual report of committee to protect journalists. New York, NY: Committee to Protect Journalists. Retrieved from https://cpj.org/about/CPJ.2018.Annual.Report.pdf

Creech, B. (2018). Bearing the cost to witness: the politi- 
cal economy of risk in contemporary conflict and war reporting. Media, Culture \& Society, 40(4), 567-583. https://doi.org/10.1177/0163443717715078

Diedong, A. L. (2016). Donkor: A case study of the safety of journalists in Ghana. Global Media Journal: African Edition, 10(2), 92-120.

Dowding, K. (2008). Agency and structure: Interpreting power relationships. Journal of Power, 1(1), 21-36. https://doi.org/10.1080/17540290801943380

Düsterhöft, I. (2013). The protection of journalists in armed conflicts: How can they be better safeguarded? Utrecht Journal of International and European Law, 29(76), 4-22.

DW Bengali. (2019, May 3). Kormokhetre Onichaotar Provab Sadhi Sangbadikotai [Free journalism under pressure from the fear of losing jobs]. DW Bengali. Retrieved from https://bit.ly/3a9Ap12

Eide, E., Khalvatgar, A. M., \& Shirzad, H. (2019). Afghan journalists in a balancing act: Coping with deteriorating security. Conflict \& Communication Online, 18(1), 1-16. Retrieved from https://doaj.org/article/ 1 ea7bd8a5c24479fb4026eb48e9b0273

Elahi, M. (2013). "They are not different from others": Ethical practices and corruption in Bangladeshi journalism. Journal of Mass Media Ethics, 28(3), 189-202.

Fadnes, I., Krøvel, R., \& Orgeret, K. S. (2019). Where are we now?-(Almost) a decade with the UN plan of action on the safety of journalists and the issue of impunity. Conflict \& Communication Online, 18(1), 1-6.

Freedom House. (2019). Bangladesh. Freedom House. Retrieved from https://freedomhouse.org/report/ freedom-world/2019/bangladesh

Goffman, E. (1974). Frame analysis: An essay on the organization of experience. Cambridge, MA: Harvard University Press.

Greppi, M. (2004). News pools as Iraq heats up. TelevisionWeek, 23(15), 3-70. Retrieved from http:// unr.idm.oclc.org/login?url=https://search.proquest. com/docview $/ 203842036$ ?accountid $=452$

Hodal, K. (2019, February 28). Study warns of global rise in autocratic leaders 'hijacking' laws for own ends. The Guardian. Retrieved from https://www. theguardian.com/global-development/2019/feb/ 28/study-warns-of-rise-in-autocratic-leadershijacking-laws-for-own-ends-world-justice-projectglobal-justice-index

Høiby, M., \& Ottosen, R. (2017). Journalism under pressure in conflict zones: A study of journalists and editors in seven countries. Media, War \& Conflict, 12(1), 69-86. https://doi.org/10.1177/1750635217728092

Hughes, S., \& Vorobyeva, Y. (2019). Explaining the killing of journalists in the contemporary era: The importance of hybrid regimes and subnational variations. Journalism. Advance online publication. https://doi. org/10.1177/1464884919885588

Human Rights Watch. (2018a). Bangladesh: Protect freedom of expression. Human Rights Watch. Re- trieved from https://www.hrw.org/news/2018/05/ 10/bangladesh-protect-freedom-expression

Human Rights Watch. (2018b). Bangladesh: Crackdown on social media. Human Rights Watch. Retrieved from https://www.hrw.org/news/2018/10/ 19/bangladesh-crackdown-social-media?fbclid= IwAR3VYdPgrNqDB70mFI1ikB-VObQ_hBSA6FvCbmhN7i7b-MieLabacRZgA

Islam, A., \& Rahman, M. (2016). A conceptual analysis and understanding of press freedom from Bangladesh perspective. Global Media Journal: Pakistan Edition, 9(1), 1-12.

Islam, Z., \& Jahan, N. (2019, November 29). Media: Between a rock and a hard place. The Daily Star. Retrieved from https://www.thedailystar.net/starweekend/news/media-between-rock-and-hardplace-1833088

Kim, H. S. (2010). Forces of gatekeeping and journalists' perceptions of physical danger in post-Saddam Hussein's Iraq. Journalism \& Mass Communication Quarterly, 87(3/4), 484-500. https://doi.org/10.1177/ 107769901008700303

Kollol, K. (2019, 31 October). Bangladesher gonomardhome govir songkot: Kormider modhe chakri haranor voy toiri hoyeche [Bangladeshi media in deep crisis: Fear of losing jobs among media professionals]. $B B C$ Bengali. Retrieved from https://www.bbc.com/ bengali/news-50233043

Laurent, O. (2018, August 6). Bangladeshi photographer Shahidul Alam arrested over 'provocative comments.' The Washington Post. Retrieved from https://www.washingtonpost.com/world/2018/ 08/06/bangladeshi-photographer-shahidul-alamarrested-over-provocative-comments

Lisosky, J. M., \& Henrichsen, J. (2009). Don't shoot the messenger: Prospects for protecting journalists in conflict situations. Media, War \& Conflict, 2(2), 129-148. https://doi.org/10.1177/ 1750635209104651

Löffelholz, M. (2014). Embedded journalism. Britannica Academic. Retrieved from https://academic.eb.com/ levels/collegiate/article/embedded-journalism/ 606068

Lührmann, A., \& Wilson, M. (2018, July 4). One-third of the world's population lives in a declining democracy. That includes the United States. The Washington Post. Retrieved from https://wapo.st/35UP24I

Mahmud, F. (2018a, May 14). Bangladesh students demand abolition of job quota system. Al Jazeera. Retrieved from https://www.aljazeera.com/news/ 2018/05/bangladesh-students-demand-abolitionjob-quota-system-180514110715636.html

Mahmud, F. (2018b, October 16). Bangladesh editors protest 'chilling' digital security act. Al Jazeera. Retrieved from https://www.aljazeera.com/news/ 2018/10/bangladesh-editors-protest-chillingdigital-security-law-181015122440417.html

Manab Zamin. (2019). Nirapotta Cheye Sylhet e 56 
Shangbadiker GD [56 electronic media journos file GD in Sylhet seeking safety]. Manab Zamin. Retrieved from https://m.mzamin.com/article.php? mzamin=191500

Nelson, T. E., Clawson, R. A., \& Oxley, Z. M. (1997). Media framing of a civil liberties conflict and its effect on tolerance. American Political Science Review, 91(3), 567-583.

Palinkas, L. A., Horwitz, S. M., Green, C. A., Wisdom, J. P., Duan, N., \& Hoagwood, K. (2015). Purposeful sampling for qualitative data collection and analysis in mixed method implementation research. Administration and Policy in Mental Health and Mental Health Services Research, 42(5), 533-544.

Privacy International. (2018). Updated: Amid crackdown in Bangladesh, government forces continue spytech shopping spree. Privacy International. Retrieved from https://privacyinternational.org/long$\mathrm{read} / 2226 /$ updated-amid-crackdown-bangladeshgovernment-forces-continue-spytech-shoppingspree

Relly, J. E., \& Bustamante, C. G. (2014). Silencing Mexico: A study of influences on journalists in the northern states. The International Journal of Press/Politics, 19(1), 108-131. https://doi.org/10. $1177 / 1940161213509285$

Reporters Without Borders. (2019). Index details: Data of press freedom ranking 2019. Reporters Without Borders. Retrieved from https://rsf.org/en/ranking_ table

Riaz, A. (2019). Voting in a hybrid regime: Explaining the 2018 Bangladesh election. Singapore: Palgrave Macmillan.

Saboory, M. H., Inkinen, S., Din, N. U., Rehmat, A., San Diego, T. P., Tuazon, R., . . . Shaw, R. (2017). Defending journalism: How national mechanisms can protect journalists and address the issue of impunity. Copenhagen: International Media Support. Retrieved from https://www.mediasupport.org/wpcontent/uploads/2017/10/1_Journalist-ProtectionBook-Digital-1.pdf
Scheufele, D. A. (2000). Agenda-setting, priming, and framing revisited: Another look at cognitive effects of political communication. Mass Communication \& Society, 3(2/3), 297-316.

Schlosser, M. (2015). Agency. The Stanford Encyclopedia of Philosophy. Retrieved from https://plato.stanford. edu/archives/fall2015/entries/agency

Schwarz, R. (2018). Democracy under pressure: Polarization and repression are increasing worldwide. Bertelsmann Stiftung. Retrieved from https://www. bertelsmann-stiftung.de/en/press/press-releases/ press-release/pid/democracy-under-pressurepolarization-and-repression-are-increasingworldwide/\#1

Srinivasan, I. (2016). Journalists' safety in the world's most restricted regime: The case of Eritrea, Northeast Africa. Global Media Journal: African Edition, 10(2), 35-67.

The Daily Star. (2018, August 6). Journos attacked while on duty. The Daily Star. Retrieved from https:// www.thedailystar.net/city/5-photojournalists-hurtin-bcl-men-attack-science-lab-dhaka-studentprotest-for-safe-roads-1616251

The Economist. (2018, July 23). The global slump in press freedom. The Economist. Retrieved from https://www.economist.com/graphic-detail/2018/ 07/23/the-global-slump-in-press-freedom

Tumber, H. (2006). The fear of living dangerously: Journalists who report on conflict. International Relations, 20(4), 439-451. https://doi.org/10.1177/ 0047117806069405

UNESCO. (2019). Safety of journalists. UNESCO. Retrieved from https://en.unesco.org/themes/safetyjournalists

Vannette, D. L., \& Krosnick, J. A. (Eds.). (2018). The Palgrave handbook of survey research. London: Palgrave Macmillan.

Wanta, W., \& Hu, Y. W. (1994). The effects of credibility, reliance, and exposure on media agenda-setting: A path analysis model. Journalism Quarterly, 71(1), 90-98.

\section{About the Authors}

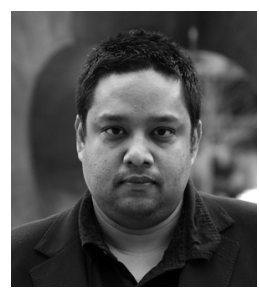

Mubashar Hasan (PhD) is a Researcher at the University of Oslo, Norway. He is also an adjunct Research Fellow (Humanitarian and Development Research Initiative, Western Sydney University, Australia), and Assistant Professor (on-leave, Political Science, North South University, Bangladesh). He is the author of Islam and Politics: Followers of Ummah (Palgrave Macmillan, 2020), and the lead Editor of the book Radicalization in South Asia (Sage, 2019). Formerly he worked as a free-lance humanitarian journalist for The New Humanitarian for four years.

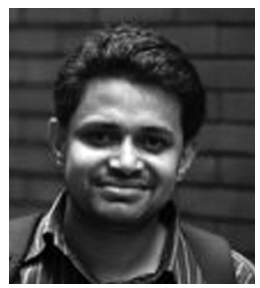

Mushfique Wadud is Graduate Student at University of Nevada, Reno, USA. He was a news reporter based in South Asia and covered the region for more than one decade. His research interests focus on press freedom, safety of journalists, political communication, media concentration, and freelance journalists. 